\title{
Genotypic Diversity and Resistance to Azoxystrobin of Cercospora beticola on Processing Table Beet in New York
}

Niloofar Vaghefi and Frank S. Hay, School of Integrative Plant Sciences, Plant Pathology \& Plant-Microbe Biology Section, Cornell University, Geneva, NY 14456; Julie R. Kikkert, Cornell Cooperative Extension, Canandaigua, NY 14424; and Sarah J. Pethybridge, School of Integrative Plant Sciences, Plant Pathology \& Plant-Microbe Biology Section, Cornell University, Geneva, NY 14456

\begin{abstract}
Vaghefi, N., Hay, F. S., Kikkert, J. R., and Pethybridge, S. J. 2016. Genotypic diversity and resistance to azoxystrobin of Cercospora beticola on processing table beet in New York. Plant Dis. 100:1466-1473.

Cercospora leaf spot (CLS), caused by Cercospora beticola, is one of the major diseases affecting productivity and profitability of beet production worldwide. Fungicides are critical for the control of this disease and one of the most commonly used products is the quinone outside inhibitor $\left(\mathrm{Q}_{\mathrm{O}} \mathrm{I}\right)$ azoxystrobin. In total, $150 \mathrm{C}$. beticola isolates were collected from two commercial processing table beet fields in Batavia, NY in 2014. The mating types of the entire population were determined, and genetic diversity of a subset of samples $(n=48)$ was assessed using five microsatellite loci. Sensitivity to azoxystrobin was tested using a spore germination assay. The cytochrome $b$ gene was sequenced to check for the presence of point mutations known to confer $\mathrm{Q}_{\mathrm{O}} \mathrm{I}$ resistance in fungi. High allelic diversity $\left(\mathrm{H}_{\mathrm{e}}=0.50\right)$ and genotypic diversity $\left(\mathrm{D}^{*}=0.96\right)$, gametic

equilibrium of the microsatellite loci, and equal ratios of mating types were suggestive of a mixed mode of reproduction for $C$. beticola. Resistance to azoxystrobin was prevalent because $41 \%$ of the isolates had values for effective concentrations reducing spore germination by $50 \%\left(\mathrm{EC}_{50}\right)>0.2 \mu \mathrm{g} / \mathrm{ml}$. The G143A mutation, known to cause $\mathrm{Q}_{\mathrm{O}} \mathrm{I}$ resistance in $C$. beticola, was found in isolates with $\mathrm{EC}_{50}$ values between 0.207 and $19.397 \mu \mathrm{g} / \mathrm{ml}$. A single isolate with an $\mathrm{EC}_{50}$ of $0.272 \mu \mathrm{g} / \mathrm{ml}$ carried the F129L mutation, known to be associated with low levels of $\mathrm{Q}_{\mathrm{O}} \mathrm{I}$ resistance in fungi. This is the first report of the F129L mutation in C. beticola. The implications of these findings for the epidemiology and control of CLS in table beet fields in New York are discussed.
\end{abstract}

New York is the second largest producer of processing and fresh market table beet (Beta vulgaris L.) in the United States (United Stated Department of Agriculture National Agricultural Statistics Service 2012). The processing table beet industry, based in western New York, is worth $\$ 1,800,000$, with more than 1,000 ha under cultivation. Fresh market beet crops are produced by approximately 240 farms throughout the state, with an estimated value of $\$ 8,300,000$ over approximately 320 ha (United Stated Department of Agriculture National Agricultural Statistics Service 2012).

Cercospora leaf spot (CLS), caused by Cercospora beticola Sacc., is one of the most destructive diseases of both table beet and sugar beet (B. vulgaris) worldwide (Franc 2010; Koike et al. 2010). Symptoms of the disease are light brown or tan spots, usually with red to purple margins, which turn gray after sporulation. Under conducive environmental conditions (elevated humidity and temperatures between 26 and $32^{\circ} \mathrm{C}$ ), the spots expand and coalesce into necrotic lesions that may encompass the entire leaf surface (Koike et al. 2010). Yield losses are associated with the reduction in the photosynthetic leaf area and deterioration of the leaves, which reduce root mass and quality. In addition, loss of foliage may cause substantial or even complete yield loss in table beet crops that are harvested by toppulling machinery.

The inoculum initiating CLS epidemics consists of conidia produced within the pseudostromata in the infected plant material (Franc 2010; Pool and McKay 1916). Conidia are disseminated through water splash and by wind, and symptoms appear 11 to 13 days after infection (McKay and Pool 1918). Under favorable conditions, the latent period is reduced to 5 days and sporulation takes place as early as 3 days after lesions form. Following the first sporulation event, lesions continue to sporulate every 4 days and multiple infection cycles

Corresponding author: S. J. Pethybridge; E-mail: sjp277@cornell.edu

Accepted for publication 31 December 2015.

http://dx.doi.org/10.1094/PDIS-09-15-1014-RE

(C) 2016 The American Phytopathological Society occur within one season, fostering polycyclic epidemics (Pool and McKay 1916; Weiland and Koch 2004).

No teleomorph has been identified for $C$. beticola but recent studies have reported the presence of two alternate mating types (Groenewald et al. 2006) and their equal distribution in some sugarbeet-producing areas in Europe and the United States (North Dakota and Minnesota), suggesting the presence of cryptic sex in the life cycle of $C$. beticola (Bolton et al. 2012b; Groenewald et al. 2008). Moreover, characterization of $C$. beticola populations in sugar beet fields using microsatellite and amplified fragment length polymorphism markers identified high genetic diversity and linkage equilibrium of loci in some areas, which is also suggestive of sexual recombination (Bolton et al. 2012b; Groenewald et al. 2007, 2008). In other sugar beet-growing areas, skewed frequencies of mating types or the presence of only one mating type indicated the probable lack of sexual reproduction (Bakhshi et al. 2011; Obuya et al. 2011). Knowledge of the pathogen's reproductive strategy and genetic diversity is imperative for fully understanding the epidemiology of the disease and evolutionary adaptability of the pathogen, as well as the design of integrated disease management programs (Milgroom 1996). However, such information for populations of $C$. beticola causing CLS on table beet is lacking.

CLS management in table beet production in New York is achieved through a combination of methods, including crop rotation, burial of plant debris, and regular application of fungicides (Koike et al. 2010). The use of strobilurin fungicides has been central for the management of CLS and pocket rot, the latter caused by Rhizoctonia solani (Olaya and Abawi 1994). However, in 2012, failures in control of CLS were observed despite repeated applications of azoxystrobin (Quadris; Syngenta Crop Protection Greensboro, NC) in a processing table beet field in western New York (Abawi et al. 2014). The cause of this failure was attributed to strobilurin resistance detected through an in vitro mycelial growth assay (Abawi et al. 2014). Because strobilurin fungicides inhibit adenosine triphosphate (ATP) production, germinating spores are more sensitive to these fungicides than mycelia (Fernández-Ortuño et al. 2008; Secor and Rivera 2011). However, the presence of $C$. beticola isolates from processing table beet fields in New York State that have reduced 
sensitivity to strobilurin fungicides has not been confirmed using a spore germination assay.

Strobilurin fungicides belong to the quinone outside inhibitor (QOI; Fungicide Resistance Action Committee group 11) group of fungicides which bind to the quinol oxidation $\left(\mathrm{Q}_{\mathrm{O}}\right)$ site of the cytochrome $\mathrm{bc}_{1}$ enzyme complex, resulting in the inhibition of ATP production and reduction in energy production by the fungus (Bartlett et al. 2002; Fisher and Meunier 2008). The single-site mode of action inherent within $\mathrm{Q}_{\mathrm{O}} \mathrm{I}$ fungicides means that fungal sensitivity to the active ingredient is easily overcome by point mutations in the target site within the cytochrome $b$ (cytb) gene (Fernández-Ortuño et al. 2010; Gisi et al. 2002). Thus, $\mathrm{Q}_{\mathrm{O}} \mathrm{I}$ fungicides are considered to be at high risk for resistance development. Since the introduction of Qo I to market in the mid-1990s, isolates of more than 50 species of plant-pathogenic fungi have developed resistance to these fungicides (Fernández-Ortuño et al. 2010; Fungicide Resistance Action Committee 2013).

The rapid development of high levels of resistance to $\mathrm{Q}_{\mathrm{O}} \mathrm{I}$ fungicides in fungal pathogens has predominantly been attributed to a point mutation at amino acid position 143, which results in the substitution of glycine by alanine (G143A) in the cytochrome $b_{1}$ complex (Fernández-Ortuño et al. 2010). Substitution of phenylalanine with leucine at codon 129 (F129L) has been associated with moderate levels of resistance to $\mathrm{Q}_{\mathrm{O}} \mathrm{I}$ in some phytopathogenic fungi (Kim et al. 2003), and may be overcome by more frequent fungicide applications or increased rates of application of fungicides (FernándezOrtuño et al. 2008; Gisi et al. 2002). A third mutation, G137R, has only been observed in Pyrenophora tritici-repentis in wheat (Sierotzki et al. 2007). Moreover, a G143S mutation associated with reduced sensitivity to $\mathrm{Q}_{\mathrm{O}} \mathrm{I}$ has been found in laboratory mutants of C. beticola and Magnaporthe grisea but has not been detected in field populations (Avila-Adame and Köller 2003; Malandrakis et al. 2006). A second mechanism of resistance to $\mathrm{Q}_{\mathrm{O}} \mathrm{I}$ fungicides is through activation of the alternative respiration pathway (FernándezOrtuño et al. 2008), which is believed to occur predominantly in vitro (Ziogas et al. 1997). However, some studies have suggested that it may also play an important role in resistance development in field populations (Ishii et al. 2009; Wood and Hollomon 2003). Resistance to $\mathrm{Q}_{\mathrm{O}} \mathrm{I}$ in populations of $C$. beticola on sugar beet in Europe and the United States is well documented and, to date, has only been found associated with the G143A mutation (Birla et al. 2012; Bolton et al. 2012a, 2013; Kirk et al. 2012; Rosenzweig et al. 2015).

Knowledge of the occurrence, frequency, and evolution of fungicide resistance in $C$. beticola populations in New York is vital to evaluate and improve the processing table beet disease management program, and for development of management strategies for fungicide resistance. Although this disease has been studied in depth in sugar beet, analogous studies on table beet and in the eastern United States are lacking. The objectives of this study were to (i) understand the genetic diversity and potential for sexual reproduction of the C. beticola populations associated with two processing table beet fields in New York and (ii) quantify the frequency and nature of $\mathrm{Q}_{\mathrm{O}} \mathrm{I}$ resistance in these two populations.

\section{Materials and Methods}

Field histories and fungal isolations. Isolates of $C$. beticola were collected from two commercial processing beet fields, both planted with 'Ruby Queen' beet (Skagit Seed Services, Mount Vernon, WA) in Batavia, NY in 2014, hereafter referred to as field 1 (15.5 ha) and field 2 (1.9 ha). These fields were $300 \mathrm{~m}$ apart and isolated from other table beet fields by $5 \mathrm{~km}$. Both fields were planted to alfalfa (Medicago sativa L.) from 2009 to 2013, in accordance with the well-established practice of long rotation periods (at least 3 years) for CLS management. During the 2014 season, both fields received azoxystrobin (Quadris; Syngenta Crop Protection) at 0.19 liters of active ingredient (a.i.)/ha applied in-furrow at planting to control pocket rot. A second application contained a mixture of azoxystrobin (Quadris) at 0.19 liters a.i./ha and propiconazole (Tilt; Syngenta Crop Protection) at 0.12 liters a.i./ha as a foliar application 61 days after planting.
In each field, symptomatic leaves $(n=90)$ were collected along two transects by sampling 15 leaves at each of the three sampling points per transect, with sampling points $100 \mathrm{~m}$ apart. Leaves were stored at $5^{\circ} \mathrm{C}$ for a maximum of 7 days before isolation. For isolation, leaves were rinsed with sterile distilled water and placed in glass petri plates in humid boxes, at room temperature, to induce sporulation. After 3 to 4 days, conidia from a single lesion per leaf were transferred to potato dextrose agar (PDA; Hardy Diagnostics, Santa Maria, CA) and pure cultures were obtained after $24 \mathrm{~h}$ by hyphaltip transfer of the germinating spores to fresh PDA plates, using a fine needle and a dissecting microscope. Pure cultures, maintained at room temperature $\left(22\right.$ to $\left.24^{\circ} \mathrm{C}\right)$ with a photoperiod of $12 \mathrm{~h}$ of white fluorescent light and $12 \mathrm{~h}$ of darkness, were used for genotyping and fungicide sensitivity testing.

DNA extraction and $C$. beticola-specific polymerase chain reaction assay. Liquid cultures were established for all isolates by transferring mycelia from 2-week-old $C$. beticola cultures into $20 \mathrm{ml}$ of broth (Czapek-Dox at $35 \mathrm{~g} /$ liter; BD, Franklin Lakes, NJ). Two-week-old mycelia were harvested and lyophilized. The lyophilized mycelium $(25 \mathrm{mg})$ of each isolate was ground to a fine powder in a 2-ml microcentrifuge tube (Safe-Lock tubes; Eppendorf, Hauppauge, NY) using two 4.5-mm-diameter, zinc-plated, spherical balls (premium-grade BBs; Daisy, Rogers, AR) in a TissueLyser (Qiagen, Valencia, CA). Genomic DNA for each isolate was extracted using a DNA extraction kit (DNeasy Plant Minikit; Qiagen) according to the manufacturer's instructions. Quantity of the DNA was determined using a fluorometer (Qubit 2.0; Invitrogen, Inc., Grand Island, NY). The integrity of the DNA samples was checked through electrophoresis on an agarose gel $(1 \%$ [wt/vol] agarose in Tris-acetate-EDTA) amended with $0.5 \times(\mathrm{vol} / \mathrm{vol})$ nucleic acid stain GelRed (Biotium, Inc., Hayward, CA).

To confirm pathogen identity, isolates were screened by a conventional polymerase chain reaction (PCR) assay using the C. beticolaspecific primers CercoCal-beta and CercoCal-R (Groenewald et al. 2005). The PCR mix (15 $\mu$ l total volume) contained $1 \times$ standard PCR buffer (New England Biolabs, Inc., Ipswich, MA), $1.5 \mathrm{mM}$ $\mathrm{MgCl}_{2}$ (New England Biolabs, Inc.), $0.1 \mathrm{mM}$ dNTP (New England Biolabs, Inc.), $0.2 \mu \mathrm{M}$ each of the forward and reverse primers, $0.8 \mathrm{U}$ of Taq polymerase (New England Biolabs, Inc.), and $10 \mathrm{ng}$ of template DNA. The PCR conditions included an initial denaturation for $5 \mathrm{~min}$ at $95^{\circ} \mathrm{C}$; followed by 38 cycles of denaturation at $95^{\circ} \mathrm{C}$ for $30 \mathrm{~s}$, annealing at $60^{\circ} \mathrm{C}$ for $20 \mathrm{~s}$, and extension at $68^{\circ} \mathrm{C}$ for $20 \mathrm{~s}$; and a final extension at $68^{\circ} \mathrm{C}$ for $5 \mathrm{~min}$. PCR assays were conducted in a T100 Thermal Cycler (Bio-Rad, Hercules, CA) and visualized on a $1 \%$ agarose gel, as described above.

Genotyping. In total, 48 C. beticola isolates ( 24 isolates from each field) were arbitrarily chosen for microsatellite genotyping to assess population diversity in the two fields. Genotyping was conducted using five microsatellite markers developed by Groenewald et al. (2007). For each locus, one of the primers was tagged with one of the following fluorescent dyes: SSRCb1-NED, SSRCb2-6FAM, SSRCb36FAM, SSRCb4-PET, or SSRCb6-VIC.

Loci SSRCb2/SSRCb6 and SSRCb1/SSRCb3 were amplified in duplex PCR assays. The PCR mix (15 $\mu$ l total volume) consisted of $10 \mathrm{ng}$ of DNA, standard PCR buffer, $0.2 \mathrm{mM}$ dNTP, $1.5 \mathrm{mM}$ $\mathrm{MgCl}_{2}, 1 \mathrm{U}$ of Taq polymerase, and optimized concentrations of primers $(0.2 \mu \mathrm{M}$ for SSRCb1 and SSRCb6, $0.3 \mu \mathrm{M}$ for SSRCb2, and $0.4 \mu \mathrm{M}$ for SSRCb3). The SSRCb4 locus was amplified in a uniplex PCR with $0.2 \mu \mathrm{M}$ of each primer, as described above. The amplification was performed in a T100 Thermal Cycler and consisted of a 5 min initial denaturation step $\left(95^{\circ} \mathrm{C}\right)$ followed by 40 cycles of $30 \mathrm{~s}$ at $95^{\circ} \mathrm{C}, 30 \mathrm{~s}$ at $55^{\circ} \mathrm{C}$, and $30 \mathrm{~s}$ at $68^{\circ} \mathrm{C}$; and a final $5 \mathrm{~min}$ elongation step $\left(68^{\circ} \mathrm{C}\right)$. Fluorescent-labeled products for each isolate were pooled into one bin and analyzed using the GeneScan-500 LIZ size standard (Applied Biosystems) on an ABI 3730xl DNA Analyzer at Cornell University Institute of Biotechnology Genomic Diversity Facility, Ithaca, NY. Alleles were scored using the Geneious Microsatellite Plugin, version 1.4 (Geneious, version 7.1.8; http://www.geneious.com; Kearse et al. 2012). To reduce genotyping error, isolates showing null alleles were rerun. Genotyping was 
replicated for $50 \%$ of the samples to confirm reproducibility, and to quantify error rate per locus ( $\left.e_{1}\right)$ (Pompanon et al. 2005). When variable sizing was detected between the two replicates, genotyping was conducted for a third time.

Data analysis. For each population of $C$. beticola, average allelic diversity $\left(\right.$ Nei's $\mathrm{H}_{\mathrm{e}}$ ) was calculated in Arlequin, version 3.5.2.1 (Excoffier et al. 2005). Genotypic diversity (D*), richness (R), and evenness were calculated using Genclone (Arnaud-Haond and Belkhir 2007). Significant differences in genotypic diversities between the two populations was tested in GenoDive (Meirmans and van Tienderen 2004) using 999 bootstrapped data set sampling. Analysis of molecular variance (AMOVA) was conducted in Arlequin, version 3.5.2.1 to determine the partitioning of genetic variation within and between the two populations, using the unbiased estimator of the fixation index $\left(\mathrm{F}_{\mathrm{ST}}\right)$, the significance of which was tested using 10,000 permutations. AMOVA revealed no significant genetic differentiation between the two fields, allowing all of the isolates to be pooled as one population and estimate the genetic diversity indices as described above. The number of multilocus genotypes (MLG) in each field, the number of recurrent genotypes, and their frequency between fields were calculated using the $\mathrm{R}$ package (Poppr, version 1.1.5) (Kamvar et al. 2014).

A minimum spanning network of the entire population was constructed based on Bruvo's distance (Bruvo et al. 2004) using Poppr, version 1.1.5 (Kamvar et al. 2014). Bruvo's method uses a stepwise mutation model to calculate genetic distance between MLG; thus, the length of the repeat motif for each locus needed to be defined. Locus SSRCb4 contained an incomplete repeat (AAAAGAAGAGAGA; Groenewald et al. 2007) which could have resulted in variable nucleotide repeat differences (mono, di, or tri) between the MLG. In this study, SSRCb4 was defined as a di-nucleotide repeat.

Frequency of random mating. To gain insight into the reproductive mode of $C$. beticola populations in the two processing table beet crops in New York, random mating was tested using two approaches. First, the mating type for each isolate was determined in a multiplex PCR assay using the primer combinations CercosporaMat1F/R (Groenewald et al. 2006) and 356/358 (Bolton et al. 2012b). To amplify the MAT1-2 allele, CercosporaMat2 primers developed by Groenewald et al. (2006) were first tested. These primers failed to amplify a single band in the MAT1-2 isolates within these populations. Therefore, primer pair 356/358 (Bolton et al. 2012b) was used for mating type determination. The PCR mix (20 $\mu$ l total volume) included $10 \mathrm{ng}$ of DNA, standard PCR buffer, $0.1 \mathrm{mM}$ dNTP, $1 \mathrm{mM} \mathrm{MgCl} 2,0.8 \mathrm{U}$ Taq of polymerase, and $0.1 \mu \mathrm{M}$ each primer. The amplification was performed on a T100 Thermal Cycler and consisted of a 5 -min initial denaturation step $\left(95^{\circ} \mathrm{C}\right)$; followed by 40 cycles of $30 \mathrm{~s}$ at $95^{\circ} \mathrm{C}, 30 \mathrm{~s}$ at $61^{\circ} \mathrm{C}$, and $30 \mathrm{~s}$ at $68^{\circ} \mathrm{C}$; and a final 5 -min extension at $68^{\circ} \mathrm{C}$. PCR products were separated by agarose gel electrophoresis, as described above. Isolates containing the MAT1-1 allele were expected to produce an 805-bp amplicon, whereas MAT1-2 isolates were expected to produce a 442-bp amplicon. The hypothesis of random mating was tested by quantifying significant departures of mating type frequencies from a 1:1 ratio expected under random mating, with a $\chi^{2}$ goodness-of-fit test (SPSS, v. 22.0.0.0). This was conducted for both the global (defined herein as not clone-corrected) and clone-corrected datasets. For clone correction, isolates with the same $c y t b$ allele (outlined below) and MLG were considered clonal.

In the second approach, a null hypothesis of panmixia, representing a random association of alleles, was tested using Poppr, version 1.1.5 (Kamvar et al. 2014) by calculating the standardized index of association $\bar{r}_{\mathrm{d}}$ (Agapow and Burt 2001). Departure from the null hypothesis (no linkage; $\bar{r}_{\mathrm{d}}=0$ ) was tested using 1,000 permutations. In randomly mating populations, an $\bar{r}_{\mathrm{d}}$ value equal to zero is expected. Alternatively, an $\bar{r}_{\mathrm{d}}$ value significantly different from zero is indicative of linkage among loci and population clonality. A second test of linkage disequilibrium was conducted in GenALEx, version 5 (Peakall and Smouse 2006) through estimating observed variance of differences between individuals/expected variance ( $\mathrm{Vo} / \mathrm{Ve})$, and a significant departure from a value of 1 was tested using
999 permutations. Both measures were estimated for the global and clone-corrected datasets.

Sensitivity to azoxystrobin. Sensitivity of $C$. beticola isolates to azoxystrobin was evaluated using a conidial germination assay. Technical-grade azoxystrobin (Sigma-Aldrich, St. Louis) was dissolved in acetone to make a stock solution of $10,000 \mu \mathrm{g}$ a.i. $/ \mathrm{ml}$. The test medium was prepared by cooling $3 \%$ water agar (WA) to $55^{\circ} \mathrm{C}$ and adding variable amounts of the azoxystrobin stock solution to achieve concentrations of $0.001,0.01,0.1,1.0,10,25$, and $100 \mu \mathrm{g}$ a.i./ml. All fungicide-amended plates contained salicylhydroxamic acid (SHAM; Sigma-Aldrich) at $60 \mu \mathrm{g} / \mathrm{ml}$ to suppress the alternative respiration pathway (Bradley and Pedersen 2011). The effect of SHAM on conidial germination in five arbitrarily selected isolates was assessed by a generalized linear model with a completely randomized design using GenStat, version 17.1 (VSN International, Hemel Hempstead, Hertfordshire, United Kingdom), which determined that SHAM at $60 \mu \mathrm{g} / \mathrm{ml}$ was the greatest concentration tested that did not significantly decrease conidial germination $(P \geq 0.05$; data not shown). Nonamended control plates consisted of $3 \%$ WA and SHAM at $60 \mu \mathrm{g} / \mathrm{ml}$. The final concentrations of the solvents were the same for all treatments and did not exceed $1 \%$ (vol/vol).

To produce inocula, isolates were cultured on clarified V8 (CV8) agar medium, as described by Secor and Rivera (2012), and were incubated at room temperature $\left(22\right.$ to $\left.24^{\circ} \mathrm{C}\right)$ for 6 days with a photoperiod of $12 \mathrm{~h}$ of white fluorescent light and $12 \mathrm{~h}$ of darkness. Of the 150 isolates recovered from the two fields, only 131 isolates sporulated on CV8 agar medium and, thus, were characterized for sensitivity to azoxystrobin. Conidia were harvested by flooding the plates with $5 \mathrm{ml}$ of sterile distilled water, dislodging the spores using a sterile glass spreader, and passing the suspension through four layers of sterile muslin cloth. A 50- $\mu$ l aliquot of each conidial suspension was transferred onto a square plug $\left(9 \mathrm{~mm}^{2}\right)$ of the test agar medium on a microscope slide. The plugs were each covered with a coverslip and incubated at room temperature in a tray covered with aluminum foil to prevent dehydration. Each isolate was replicated on three separate WA plugs for all the fungicide concentrations tested and the nonamended control treatment. After $24 \mathrm{~h}, 50$ conidia on each of the slides were observed at $\times 200$ magnification. Normal germination was defined as the germ tube being at least half the length of the conidium (Kirk et al. 2012). The effective concentration required to cause $50 \%$ inhibition $\left(\mathrm{EC}_{50}\right)$ of the incidence of conidial germination was calculated by probit analysis in Statistical Analysis System (SAS), version 9.4. The mean $\mathrm{EC}_{50}$ values of the two sampled fields were compared with an independent samples $t$ test in SPSS, version 22.0.0.0.

Sequencing of $\boldsymbol{c y t b}$. In all, $59 \mathrm{C}$. beticola isolates exhibiting a wide range of $\mathrm{EC}_{50}$ values were screened for the presence of fungicide resistance-related mutations in the cytb gene sequence (Birla et al. 2012; Bolton et al. 2012a). An internal fragment of $c y t b$ was amplified using the primers cytbSF (5'-ACA GCT TCA GCA TTT TTC TTC TT- $3^{\prime}$ ) and cytbSR ( $5^{\prime}$-TCT ATG AAT GGT GAT TCA ACG TG-3') (Malandrakis et al. 2006, 2011). Each PCR mix (50 $\mu$ l total volume) contained $1 \times$ standard PCR buffer, $2 \mathrm{mM} \mathrm{MgCl}, 0.2 \mathrm{mM}$ $\mathrm{dNTP}, 0.2 \mu \mathrm{M}$ forward and reverse primers, $1 \mathrm{U}$ of Taq polymerase, and $10 \mathrm{ng}$ of template DNA. The PCR conditions included an initial denaturation for $5 \mathrm{~min}$ at $95^{\circ} \mathrm{C}$; followed by 40 cycles of denaturation at $95^{\circ} \mathrm{C}$ for $30 \mathrm{~s}$, annealing at $56^{\circ} \mathrm{C}$ for $30 \mathrm{~s}$, and extension at $68^{\circ} \mathrm{C}$ for $1 \mathrm{~min}$; and a final extension at $68^{\circ} \mathrm{C}$ for $5 \mathrm{~min}$. This resulted in an approximately 850-bp amplicon for all isolates, which was then purified using a PCR purification kit (E.Z.N.A. Cycle Pure Kit; Omega Bio-Tek, Inc., Norcross, GA) according to the manufacturer's instructions. Purified products were sequenced at the Cornell University Institute of Biotechnology Genomics Facility. Primer cytbRu (5'-GAA ACT CCT AAA GGA TTA CCT GAA CC-3') (Malandrakis et al. 2006, 2011), internal to the reverse primer, was used for sequencing in the reverse direction to ensure coverage of the codons at positions 129 and 143 at the $3^{\prime}$ end of the amplicon. Sequences were visualized and aligned with Geneious, version 7.1.8 (Kearse et al. 2012). The partial $c y t b$ sequences were compared with the reference cytb sequences of the wild type (JQ619932) and resistant mutants (JQ619933) of $C$. beticola (Bolton et al. 2012b) to search for the 
presence of the G143A mutation (i.e., a G-to-C transition at position 175 of the reference sequence). Sequences were also searched manually for a C-to-A transversion at codon 129 (mutation F129L) (Pasche et al. 2005).

The presence or absence of resistance-inducing point mutations was used to establish $\mathrm{EC}_{50}$ threshold values characterizing azoxystrobin-resistant and -sensitive isolates (Birla et al. 2012). Isolates containing either of the $\mathrm{Q}_{\mathrm{O}} \mathrm{I}$-resistance point mutations G143A or F129 L were considered resistant, and isolates with the wild-type $c y t b$ sequence were regarded as sensitive. The numbers of resistant and sensitive isolates were compared between the two fields using $\chi^{2}$ analysis (SPSS, version 22.0.0.0).

\section{Results}

In total, 150 isolates of $C$. beticola were recovered from the two processing table beet fields ( 82 and 68 isolates from fields 1 and 2, respectively). C. beticola-specific PCR assay resulted in the expected 176-bp amplicon for all the isolates, thereby confirming their identities as $C$. beticola.

Genotyping. All five loci were found to be polymorphic without amplification error for all isolates examined by genotyping, except for locus CbSSR2, which showed an error rate of 0.04. Isolate Tb14-138 showed variable sizing of CbSSR2 in the two genotyping replicates (195 and $197 \mathrm{bp}$ ). A third genotyping of this isolate resulted in a 195-bp peak.

The number of alleles for the five loci ranged from 2 (CbSSR 1 and CbSSR2) to 11 (CbSSR3), with an average of 4.4 alleles/locus (Table 1). CbSSR3 was the most polymorphic locus with 11 alleles. Both fields showed high allelic diversity $\left(\mathrm{H}_{\mathrm{e}}=0.47\right.$ and 0.53 for fields 1 and 2, respectively) and genotypic diversity ( $\mathrm{D}^{*}=0.93$ and 0.94 for fields 1 and 2, respectively) (Table 1). GenoDive revealed no significant difference between the amounts of genotypic diversity present in the two fields. However, the genotypic composition of the populations differed significantly $(P=0.002)$. AMOVA in Arlequin revealed no significant genetic differentiation between the two fields $\left(\mathrm{F}_{\mathrm{ST}}=-1.28, P=0.62\right)$, indicating that all of the genetic variation detected originated within the fields. Of the total $25 \mathrm{MLG}$ that were present in the entire population, only 3 (MLG6, $n=3$; MLG13, $n=3$; and MLG19, $n=6$ ) occurred in both populations. MLG19 was the most frequent genotype in the whole population (0.125; Fig. 1). The most frequent genotypes in field 1 and field 2 were MLG1 $(n=5)$ and MLG19 $(n=5)$, respectively. The rest of the genotypes occurred one to three times in the population. For two comparisons, isolates within the same MLG had different mating types (MLG4 and MLG15) or had different $c y t b$ haplotypes (MLG3

Table 1. Genetic diversity indices for Cercospora beticola populations collected from two processing table beet fields in Batavia, NY in 2014

\begin{tabular}{lcccccccc}
\hline & & \multicolumn{7}{c}{ Diversity indices } \\
\cline { 2 - 9 } Population & Size & $\mathbf{R}_{\mathbf{a}}^{\mathbf{a}}$ & $\mathbf{P}_{\mathbf{a}}^{\mathbf{b}}$ & $\mathbf{H}_{\mathbf{e}}^{\mathbf{c}}$ & $\mathbf{M L G}^{\mathbf{d}}$ & $\mathbf{R}^{\mathbf{e}}$ & $\mathbf{E D}^{\mathbf{f}}$ & $\mathbf{D}^{* \mathbf{g}}$ \\
\hline Field 1 & 24 & 4.2 & 5 & 0.47 & 13 & 0.52 & 0.86 & 0.93 \\
Field 2 & 24 & 3.4 & 1 & 0.53 & 15 & 0.61 & 0.76 & 0.94 \\
Total & 48 & 4.4 & $\ldots$ & 0.50 & $25^{\mathrm{h}}$ & 0.51 & 0.92 & 0.96 \\
\hline
\end{tabular}

a Allelic richness = Mean number of alleles per locus calculated in GenALEx v. 5 (Peakall and Smouse 2006).

b Number of private alleles calculated in GenALEx v. 5 (Peakall and Smouse 2006).

c Nei's index of gene diversity $\left(\mathrm{H}_{\mathrm{e}}\right)$ defined as the probability that two randomly chosen alleles are different (Nei 1987).

${ }^{d}$ Number of multilocus genotypes (MLG).

e Dorken and Eckert's (2001) genotypic richness defined as $\mathrm{R}=(\mathrm{G}-1) /(\mathrm{N}-1)$, where $\mathrm{G}=$ number of genotypes and $\mathrm{N}=$ number of isolates (Arnaud-Haond and Belkhir 2007).

f Evenness = estimation of the equability in distribution of the sampling units (Arnaud-Haond and Belkhir 2007).

$\mathrm{g}$ Genotypic diversity = probability that two randomly chosen individuals have different MLG (Arnaud-Haond and Belkhir 2007).

h Total number of MLG is $<28$ because three MLG were common to both fields. and MLG22) and, therefore, were not considered clones in the AMOVA and subsequent mating type analyses.

Frequency of random mating. MAT1-1 and MAT1-2 isolates existed in equal ratios in field $1(P=0.094)$. In field 2 , the MAT1-1/ MAT1-2 ratio deviated significantly from $1(P<0.001)$. However, for the clone-corrected dataset, the mating type ratios in both fields did not deviate significantly from $1(P>0.05)$. In the global microsatellite dataset, the standardized index of association $\left(\bar{r}_{\mathrm{d}}\right)$ and $\mathrm{Vo} / \mathrm{Ve}$ ratio indicated significant linkage disequilibrium; thus, there was nonrandom association of loci in both populations. However, when datasets were clone corrected, both indices showed linkage equilibrium of loci that is expected in a panmictic population (Table 2).

Sensitivity to azoxystrobin and $\boldsymbol{c y t} \boldsymbol{b}$ sequencing. $\mathrm{EC}_{50}$ values ranged from 0.003 to $19.397 \mu \mathrm{g} / \mathrm{ml}$, with 54 isolates (41\%) having $\mathrm{EC}_{50}$ values $>0.2 \mu \mathrm{g} / \mathrm{ml}$ and 77 isolates $(59 \%)$ having $\mathrm{EC}_{50}$ values $\leq$ $0.1 \mu \mathrm{g} / \mathrm{ml}$. In field $1, \mathrm{EC}_{50}$ values were 0.003 to $19.397 \mu \mathrm{g} / \mathrm{ml}$, with a mean \pm standard error $\mathrm{EC}_{50}$ of $1.620 \pm 0.280 \mu \mathrm{g} / \mathrm{ml}$. In the second field, $\mathrm{EC}_{50}$ values were 0.003 to $5.496 \mu \mathrm{g} / \mathrm{ml}$, with a mean $\mathrm{EC}_{50}$ of $0.578 \pm 0.161 \mu \mathrm{g} / \mathrm{ml}$, which was significantly less than the mean $\mathrm{EC}_{50}$ of the $C$. beticola population from field $1(P=0.002)$.

The partial sequence of $c y t b$ was obtained for 59 C. beticola isolates with a wide range of $\mathrm{EC}_{50}$ values $(0.003$ to $19.397 \mu \mathrm{g} / \mathrm{ml}$; Fig. 2; Table 3). Heteroplasmy was not detected in any of the isolates. Isolates with $\mathrm{EC}_{50}$ values $\leq 0.1 \mu \mathrm{g} / \mathrm{ml}$ carried no mutations compared with the wild-type sequence (GenBank accession number JQ619932), and were categorized as sensitive to azoxystrobin. All isolates with $\mathrm{EC}_{50}$ values $\geq 0.2 \mu \mathrm{g} / \mathrm{ml}$ contained a single nucleotide mutation known to be associated with $\mathrm{Q}_{\mathrm{O}} \mathrm{I}$ resistance and, thus, were regarded as resistant to azoxystrobin. Therefore, $0.2 \mu \mathrm{g} / \mathrm{ml}$ was designated as the cut-off for defining isolates with azoxystrobin resistance. The frequency of the azoxystrobin-resistant and -sensitive isolates differed significantly between the two fields $\left(\chi^{2}=13.93\right.$, $\mathrm{df}=1, P<0.001)$. In field $1,57 \%$ of the isolates were azoxystrobin resistant, whereas only $23 \%$ of the isolates in field 2 were resistant.

For all but one of the resistant isolates of C. beticola $\left(\mathrm{EC}_{50}>\right.$ $0.2 \mu \mathrm{g}$ a.i./ml), a single nucleotide mutation (GGT $\rightarrow \mathrm{GCT}$ ) was present in codon 143 of $c y t b(\mathrm{G} 143 \mathrm{~A})$. A resistant isolate with an $\mathrm{EC}_{50}$

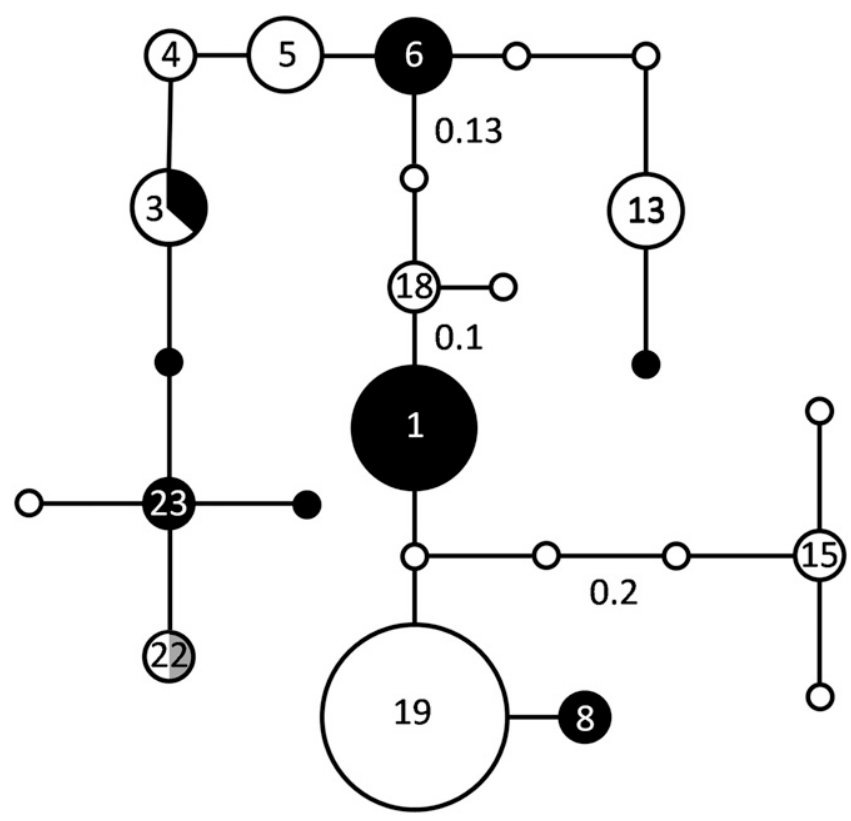

Fig. 1. Minimum spanning network for Cercospora beticola isolates from two processing table beet fields in New York in 2014 estimated using Bruvo's distance (Bruvo et al. 2004). Each node represents a multilocus genotype (MLG) and the node sizes are proportional to the frequency of the MLGs. Numbers of the most frequent MLGs are given in the nodes. The colors black and gray represent the presence of $\mathrm{G} 143 \mathrm{~A}$ and $\mathrm{F} 129 \mathrm{~L}$ mutations, respectively, in the cytochrome $b$ sequence (Bolton et al. 2013; Pasche et al. 2005). White indicates the absence of mutations. Edge length is proportional to the genetic distance between the MLGs. 
value of $0.272 \mu \mathrm{g} / \mathrm{ml}$ (Tb14-046) contained a single nucleotide polymorphism (TTC $\rightarrow$ TTA) at codon 129 , predicted to result in the F129 L mutation (Table 3). Apart from these point mutations associated with $\mathrm{Q}_{\mathrm{O}} \mathrm{I}$ resistance, no sequence variation was detected among the isolates. Representative partial nucleotide sequence data of the cytb gene for $\mathrm{Q}_{\mathrm{O}} \mathrm{I}$-sensitive and -resistant isolates were deposited in GenBank (KT364886 to KT364888).

\section{Discussion}

This is the first study to assess the genotypic diversity and mating type ratios of a $C$. beticola population ( $n=48$ isolates) from two table beet fields in New York State, providing valuable information on the biology and epidemiology of $C$. beticola in the northeastern United States. High levels of allelic and genotypic diversity were detected in both sampled fields, which has also been reported in C. beticola populations from sugar beet in the United States and Europe (Groenewald et al. 2008; Moretti et al. 2004, 2006; Turgay et al. 2010; Vereijssen 2004; Weiland et al. 2001). This finding is consistent with presence of sexual recombination in $C$. beticola populations (Milgroom 1996).

Microsatellite loci were in linkage equilibrium in the absence of clone correction, which is typical of clonal populations (Milgroom 1996), while all loci were in gametic equilibrium following clone correction. Similarly, mating type frequencies for the $C$. beticola population prior to clone correction showed significant deviation from a 1:1 ratio but, following clone correction, both sampled fields had equal distributions of MAT1-1 and MAT1-2 isolates. This is suggestive of the presence of a mixed reproductive mode within the C. beticola population (Maynard Smith et al. 2000). Although rare sexual reproduction events result in frequency-dependent selection and keep mating types in equal distributions, clonal reproduction is more frequent during the growing season, creating disequilibrium of loci (Maynard Smith et al. 2000). In the absence of sexual reproduction, one would expect a skewed ratio of mating types or presence of only one mating type in the population, as demonstrated in C. beticola populations from sugar beet in Iran (Bakhshi et al. 2011) and the Central High Plains of the United States (Obuya et al. 2011). Similar to the results of this study, Bolton et al. (2012b) detected an equal distribution of mating types within $C$. beticola populations in Minnesota and North Dakota sugar beet fields. The opposite mating types were even found on the same leaf, providing the potential opportunity for sexual reproduction after single lesions coalesce (Bolton et al. 2012b).

The genotypic diversity and equal ratios of mating types detected among $C$. beticola isolates from table beet crops in New York, although congruent with sexual reproduction of $C$. beticola, do not provide evidence that sexual reproduction occurs in table beet fields in New York. It has been suggested that the practice of incorporating plant residues into soil at the end of the growing season may prevent the sexual cycle of $C$. beticola from occurring in beet fields (Groenewald et al. 2008). This corroborates previous studies that were unable to find the sexual form in sugar beet fields or failed to induce mating of C. beticola on B. vulgaris (Bakhshi et al. 2011). Alternatively, C. beticola may be able to complete a sexual cycle on other reported hosts (Bobev et al. 2009; Hotegni Houessou et al. 2011; Lartey et al 2005; McKay and Pool 1918; Rooney-Latham et al. 2011; Vestal 1933).

An important factor in the design of effective disease management strategies is understanding the relative contribution of primary inoculum sources to CLS epidemics in table beet fields in New York. An important source of $C$. beticola inoculum is infested beet debris from previous seasons because $C$. beticola can survive up to 22 months in association with infested plant residues on the soil surface, and up to 10 months if infested residues are buried in the soil (Khan et al. 2008). For the two fields included in this study, alfalfa had been grown for the previous 5 years. Alfalfa has been reported to be slightly susceptible to C. beticola (Vestal 1933). In glasshouse inoculation trials using a $C$. beticola strain isolated from sugar beet in Iowa, one of three alfalfa plants developed symptoms (Vestal 1933). However, C. beticola was not reisolated from the symptomatic plant. Therefore, the susceptibility of alfalfa to $C$. beticola and its role in inoculum carryover between processing table beet fields requires further investigation to ensure that only nonhost crops are recommended in rotation with table beet for disease management. C. beticola is also known to infect multiple weeds (McKay and Pool 1918; Vestal 1933). Therefore, even if a nonhost crop species is cultivated in rotation with beet, $C$. beticola inoculum may still develop and survive on weed species. Monitoring fields for detection of C. beticola on weeds during the rotation periods between beet crops

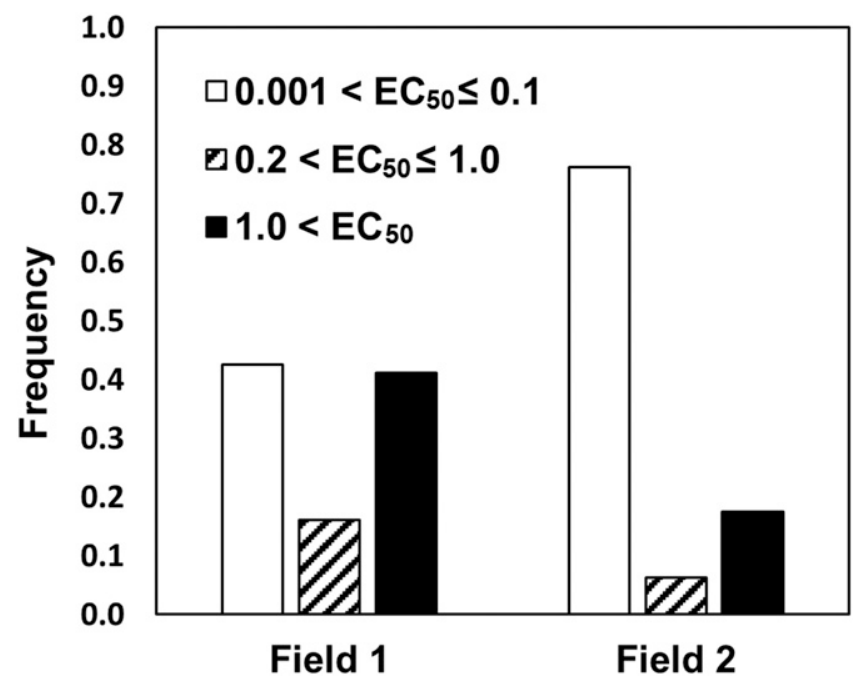

Fig 2. Frequencies of Cercospora beticola isolates with varying levels of sensitivity (effective concentrations reducing spore germination by $50 \%\left[E_{50}\right] \leq 0.1 \mu \mathrm{g} / \mathrm{ml}$ ) and resistance $\left(\mathrm{EC}_{50}>0.2 \mu \mathrm{g} / \mathrm{ml}\right)$ to azoxystrobin obtained from two processing table beet fields (68 and 63 isolates from fields 1 and 2, respectively) in Batavia, NY in 2014. The two classes of resistance were arbitrarily chosen to reflect the frequency of the varying levels of resistance in the population. Refer to the main text for details on how the $\mathrm{EC}_{50}$ values were determined for each isolate.

Table 2. Tests of multilocus association of microsatellite loci and mating type frequencies of Cercospora beticola populations from two processing table beet fields in Batavia, NY, prior to and following clone correction

Mating type frequency ${ }^{\mathbf{a}}$

\begin{tabular}{|c|c|c|c|c|c|c|c|c|c|c|}
\hline \multirow[b]{3}{*}{ Population } & \multicolumn{6}{|c|}{ Mating type frequency ${ }^{a}$} & \multirow{2}{*}{\multicolumn{2}{|c|}{$\overline{\boldsymbol{r}}_{\mathbf{d}}^{\mathbf{b}}$}} & \multirow{2}{*}{\multicolumn{2}{|c|}{$\mathrm{Vo} / \mathrm{Ve}^{\mathrm{c}}$}} \\
\hline & \multicolumn{2}{|c|}{$\begin{array}{c}\text { Prior to clone } \\
\text { correction }\end{array}$} & \multirow[b]{2}{*}{$\chi^{2}$} & \multicolumn{2}{|c|}{ Clone-corrected } & \multirow[b]{2}{*}{$x^{2}$} & & & & \\
\hline & MAT1-1 & MAT1-2 & & MAT1-1 & MAT1-2 & & Not $\mathrm{CC}$ & $\mathrm{CC}$ & Not $\mathrm{CC}$ & $\mathrm{CC}$ \\
\hline Field 1 & 0.60 & 0.40 & 2.80 & 0.62 & 0.38 & 1.00 & $0.067 * \mathrm{~b}$ & -0.051 & $1.607 *$ & 1.604 \\
\hline Field 2 & 0.78 & 0.22 & $21.06^{*}$ & 0.70 & 0.30 & 2.88 & $0.129 *$ & 0.040 & $1.687^{*}$ & 1.730 \\
\hline Total & 0.69 & 0.31 & $19.27 *$ & 0.76 & 0.33 & 3.67 & 0.008 & -0.018 & 1.371 & 1.362 \\
\hline
\end{tabular}


will provide further information on the relative contribution of weeds to CLS epidemics in table beet fields in New York.

Another plausible source of $C$. beticola is inoculum from nearby beet-growing areas. Although $C$. beticola conidia disperse mainly over short distances from plant to plant (Vereijssen 2004; Vereijssen et al. 2006, 2007), there have been reports of the conidia traveling distances of $\leq 100 \mathrm{~m}$ by wind or wind-blown rain (McKay and Pool 1918; Pool and McKay 1916). The two sampled fields were $300 \mathrm{~m}$ apart and $5 \mathrm{~km}$ from other beet-growing fields in the region. Therefore, the contribution of windborne $C$. beticola inoculum from beet fields other than these two was considered improbable in this study. This is supported by the fact that the genotypic composition of the two $C$. beticola populations was significantly different, suggesting the lack of frequent genetic exchange between the sampled fields. On the other hand, $C$. beticola has been reported to be disseminated via insects (McKay and Pool 1918; Pool and McKay 1916), implying that the introduction of $C$. beticola inoculum from other beetgrowing fields cannot be discounted completely.

Seedborne $C$. beticola has also been reported as a source of inoculum in sugar beet fields (McKay and Pool 1918). Lack of regional variation between $C$. beticola populations from sugar beet fields hundreds of kilometers apart, as well as contamination of seed-producing areas with CLS (Turgay et al. 2010), have been suggested to support the role of seedborne inoculum in long distance dispersal of C. beticola (Moretti et al. 2006; Turgay et al. 2010). The seed planted in the two sampled fields in this study originated from Mount Vernon, WA, where CLS is rare (L. du Toit, Washington State University Mount Vernon Northwestern Washington Research and Extension Center, personal communication). Thus, seedborne inoculum is unlikely to have contributed to the CLS epidemics in these fields. Moreover, the genotypic composition of the $C$. beticola populations was significantly different between the fields. For example, of a total of 25 MLG, only 3 were shared between the two fields. If $C$. beticola inoculum originated from the seed, a more uniform distribution of genotypes would have been expected. This finding could also be a function of the small number of isolates evaluated from each field $(n=24)$, which may have not been sufficient to represent all the genotypic diversity within the fields. Larger populations of $C$. beticola from various regions need to be analyzed to better understand the genetic structuring of $C$. beticola populations in New York.

$\mathrm{Q}_{\mathrm{O}} \mathrm{I}$ sensitivity tests of $C$. beticola isolates from two New York table beet fields were conducted in this study using SHAM at $60 \mu \mathrm{g} / \mathrm{ml}$ because greater concentrations were found to inhibit $C$. beticola spore germination. This suggests that the alternate respiration pathway may be essential for $C$. beticola metabolism in vitro. Inhibition of fungal growth by SHAM has been reported in other fungal pathogens, including C. zeae-maydis (Bradley and Pedersen 2011), Botrytis cinerea (De Miccolis Angelini et al. 2012), and Candida spp. (Pang et al. 2011).

To our knowledge, this is the first report of strobilurin resistance, determined using a conidial germination assay, within the $C$. beticola population from processing table beet crops in New York. Resistance of $C$. beticola to $\mathrm{Q}_{\mathrm{O}} \mathrm{I}$ fungicides in sugar beet fields in Europe and the United States has been found associated with the G143A mutation in the $c y t b$ sequence (Birla et al. 2012; Bolton et al. 2012a, 2013; Kirk et al. 2012). The G143A mutation has been reported in multiple other plant pathogens (Kim et al. 2003; Leroux et al. 2010; Lesniak et al. 2011; Ma et al. 2003; Sierotzki et al. 2007, 2008). In this study, $98 \%$ of the 54 azoxystrobin-resistant C. beticola isolates carried the G143A mutation. The G143A mutation was detected in isolates with a wide range of $\mathrm{EC}_{50}$ values $(0.207$ to $19.397 \mu \mathrm{g} / \mathrm{ml})$. These concentrations are comparable with previous reports of $\mathrm{Q}_{\mathrm{O}} \mathrm{I}$ resistance in some $C$. beticola populations: 0.344 to over $60 \mu \mathrm{g} / \mathrm{ml}$ in Birla et al. (2012) and 0.92 to $72.226 \mu \mathrm{g} / \mathrm{ml}$ in Bolton et al. (2012a).

In addition to the previously reported G143A mutation, the F129 L mutation was identified in only one $C$. beticola isolate in this study. To the best of our knowledge, this is the first report of reduced sensitivity of $C$. beticola to a strobilurin caused by the F129 L mutation. The F129 L mutation has been found associated with moderate levels of resistance in many fungal species (Kim et al. 2003; Olaya et al.
2003; Pasche et al. 2005; Semar et al. 2007; Sierotzki et al. 2008; Yamada and Sonoda 2012; Young et al. 2010). Although the presence of the F129 L mutation in Passalora fulva and Pestalotiopsis longiseta resulted in failure of azoxystrobin in disease control (Watanabe et al. 2009; Yamada and Sonoda 2012), effective control of most species with the F129 L mutation may be achieved by applying $\mathrm{Q}_{\mathrm{O}} \mathrm{I}$ at recommended application rates (Fernández-Ortuño et al. 2010; Pasche et al. 2005; Sierotzki et al. 2007). This may explain the low frequency of F129 L mutation within the New York beet C. beticola population. It has been shown that the F129 L mutation resulted in moderate resistance to azoxystrobin and did not cause cross-resistance to other $\mathrm{Q}_{\mathrm{O}} \mathrm{I}$ (Kim et al. 2003; Pasche et al. 2005). In contrast, cross-resistance to $\mathrm{QO}_{\mathrm{O}} \mathrm{I}$ has been reported frequently in fungi carrying the G143A substitutions, suggesting, that if an isolate of fungus is resistant to one $\mathrm{Q}_{\mathrm{O}} \mathrm{I}$ active ingredient, it will be resistant to all $\mathrm{Q}_{\mathrm{O}} \mathrm{I}$, as reported for C. beticola (Bolton et al. 2012a), C. sojina (Zhang et al. 2012), and C. kikuchii (Price et al. 2015). Further studies are required to understand the role of $\mathrm{F} 129 \mathrm{~L}$ in $C$. beticola resistance to $\mathrm{Q}_{\mathrm{O}} \mathrm{I}$ fungicides.

Genotyping analysis revealed that the azoxystrobin resistanceconferring mutations in the $c y t b$ gene existed in multiple MLG groups (Fig. 1), which has been taken as evidence that these mutations developed independently in multiple genetic backgrounds (Birla et al. 2012; Bolton et al. 2012b). The presence of resistance-conferring

Table 3. Sensitivity to azoxystrobin of 59 Cercospora beticola strains isolated from two processing table beet fields in Batavia, NY in 2014, and incidence of mutations in the cytochrome $b$ sequence known to be associated with resistance to quinone outside inhibitor fungicides (Bolton et al. 2013; Pasche et al. 2005) $)^{\mathrm{a}}$

\begin{tabular}{|c|c|c|c|c|c|}
\hline \multicolumn{3}{|c|}{ Field 1} & \multicolumn{3}{|c|}{ Field 2} \\
\hline Isolate & $\begin{array}{c}\mathbf{E C}_{50} \\
(\mu \mathrm{g} / \mathrm{ml})\end{array}$ & Mutation & Isolate & $\begin{array}{c}\mathbf{E C}_{50} \\
(\mu \mathrm{g} / \mathrm{ml})\end{array}$ & Mutation \\
\hline Tb14-134 & 0.003 & - & Tb14-038 & 0.020 & - \\
\hline Tb14-146 & 0.011 & - & Tb14-116 & 0.020 & - \\
\hline Tb14-023 & 0.012 & - & Tb14-036 & 0.027 & - \\
\hline Tb14-055 & 0.024 & - & Tb14-048 & 0.027 & - \\
\hline Tb14-057 & 0.026 & - & Tb14-040 & 0.029 & - \\
\hline Tb14-063 & 0.027 & - & Tb14-096 & 0.031 & - \\
\hline Tb14-003 & 0.031 & - & Tb14-051 & 0.033 & - \\
\hline Tb14-006 & 0.040 & - & Tb14-050 & 0.034 & - \\
\hline Tb14-054 & 0.040 & - & Tb14-117 & 0.034 & - \\
\hline Tb14-005 & 0.040 & - & Tb14-039 & 0.036 & - \\
\hline Tb14-140 & 0.049 & - & Tb14-052 & 0.037 & - \\
\hline Tb14-074 & 0.065 & - & Tb14-080 & 0.037 & - \\
\hline Tb14-017 & 0.074 & - & Tb14-078 & 0.038 & - \\
\hline Tb14-032 & 0.100 & - & Tb14-099 & 0.040 & - \\
\hline Tb14-004 & 0.207 & G143A & Tb14-041 & 0.042 & - \\
\hline Tb14-044 & 0.213 & G143A & Tb14-081 & 0.047 & - \\
\hline Tb14-154 & 0.310 & G143A & Tb14-109 & 0.060 & - \\
\hline Tb14-061 & 0.429 & G143A & Tb14-084 & 0.061 & - \\
\hline Tb14-068 & 0.465 & G143A & Tb14-030 & 0.070 & - \\
\hline Tb14-022 & 0.551 & G143A & Tb14-085 & 0.071 & - \\
\hline Tb14-118 & 0.536 & G143A & Tb14-042 & 0.081 & - \\
\hline Tb14-077 & 0.797 & G143A & Tb14-046 & 0.272 & F129L \\
\hline Tb14-020 & 1.344 & G143A & Tb14-097 & 0.324 & G143A \\
\hline Tb14-070 & 1.700 & G143A & Tb14-102 & 1.903 & G143A \\
\hline Tb14-069 & 2.010 & G143A & Tb14-047 & 2.555 & G143A \\
\hline Tb14-067 & 2.836 & G143A & $\ldots$ & $\ldots$ & $\ldots$ \\
\hline Tb14-090 & 3.888 & G143A & $\ldots$ & $\ldots$ & $\ldots$ \\
\hline Tb14-089 & 4.811 & G143A & $\ldots$ & $\ldots$ & $\ldots$ \\
\hline Tb14-153 & 5.574 & G143A & $\ldots$ & $\ldots$ & $\ldots$ \\
\hline Tb14-113 & 5.821 & G143A & $\ldots$ & $\ldots$ & $\ldots$ \\
\hline Tb14-138 & 5.952 & G143A & $\ldots$ & $\ldots$ & $\ldots$ \\
\hline Tb14-007 & 8.599 & G143A & $\ldots$ & $\ldots$ & $\ldots$ \\
\hline Tb14-131 & 12.926 & G143A & $\ldots$ & $\ldots$ & $\ldots$ \\
\hline Tb14-114 & 19.397 & G143A & $\ldots$ & $\ldots$ & $\ldots$ \\
\hline
\end{tabular}

a $\mathrm{EC}_{50}$ value is the effective concentration causing $50 \%$ spore germination inhibition; - indicates that no mutation was detected. 
mutations in multiple MLG, although congruent with an infraspecific parallel evolution of $\mathrm{Q}_{\mathrm{O}} \mathrm{I}$ resistance, may also be due to the uniparental inheritance of the resistant alleles through sexual reproduction (Castroagudín et al. 2015). In order to test the hypothesis that resistance arose independently in different genetic backgrounds, multiple regions of the mitochondrial DNA need to be sequenced, which will enable construction of haplotypic networks and gene genealogies to test different evolutionary scenarios (Boukef et al. 2012; Chen et al. 2007; Estep et al. 2015).

The relationship between the $\mathrm{Q}_{\mathrm{O}} \mathrm{I}$ resistance-conferring mutation G143A and fitness costs in phytopathogenic fungi has been variable. In some fungi, this mutation is reported to be associated with a fitness cost, reducing the isolates' ability to compete with wild-type isolates in the absence of fungicides (Markoglou et al. 2006; Sierotzki et al. 2008; Zhan and McDonald 2013). In contrast, in other species, the G143A mutation does not result in a fitness penalty (Banno et al. 2009; Corio-Costet et al. 2011; Sierotzki et al. 2000); hence, the resistant isolates may persist in the population even in the absence of fungicides (Zhan and McDonald 2013). Quantifying the fitness penalty associated with $\mathrm{Q}_{\mathrm{O}} \mathrm{I}$ resistance in $C$. beticola is necessary for the strategic use of fungicides (e.g., whether the $\mathrm{Q}_{\mathrm{O}} \mathrm{I}$ can be reapplied to a field after a few years alone or in a mixture following withdrawal from use in table beet fields).

In conclusion, the high genotypic and phenotypic diversity in the C. beticola population isolated from two processing table beet fields in New York, combined with the probable existence of sexual recombination based on equal frequency of mating types and linkage equilibrium of microsatellite loci, indicates a high evolutionary potential for this pathogen (McDonald and Linde 2002). The prevalence of azoxystrobin-resistant $C$. beticola isolates in the two processing table beet fields in New York and detection of multiple mechanisms associated with azoxystrobin resistance highlight the importance of regular monitoring of $C$. beticola populations for fungicide sensitivities and reducing reliance upon a $\mathrm{Q}_{\mathrm{O}} \mathrm{I}$-based fungicide program for CLS management. An additional priority is the evaluation of fungicides with different modes of action for management of CLS and other diseases of table beet in New York.

\section{Acknowledgments}

This research was supported by the United States Department of Agriculture National Institute of Food and Agriculture Hatch project NYG-625424, managed by The New York Agricultural Experiment Station, Cornell University, Geneva, NY. We thank T. Hoogland for excellent technical support; the table beet growers and the New York State vegetable processing industry that allowed access to their fields and crops for sample collection; and G. Abawi, C. Smart, L. du Toit, S. Nelson, and two anonymous reviewers for providing constructive comments on an earlier version of this article.

\section{Literature Cited}

Abawi, G. S., Kikkert, J. R., Moktan, K., Lange, H. W., and Smart, C. D. 2014. First report of resistance to Quadris among populations of Cercospora beticola causing leaf spot of table beet in New York State. (Abstr.) Phytopathology 104: S1.1.

Agapow, P. M., and Burt, A. 2001. Indices of multilocus linkage disequilibrium. Mol. Ecol. Notes 1:101-102.

Arnaud-Haond, S., and Belkhir, K. 2007. GENCLONE: A computer program to analyse genotypic data, test for clonality and describe spatial clonal organization. Mol. Ecol. Notes 7:15-17.

Avila-Adame, C., and Köller, W. 2003. Characterization of spontaneous mutants of Magnaporthe grisea expressing stable resistance to the Qo-inhibiting fungicide azoxystrobin. Curr. Genet. 42:332-338.

Bakhshi, M., Arzanlou, M., and Babai-Ahari, A. 2011. Uneven distribution of mating type alleles in Iranian populations of Cercospora beticola, the causal agent of Cercospora leaf spot disease of sugar beet. Phytopathol. Mediterr. 50:101-109.

Banno, S., Yamashita, K., Fukumori, F., Okada, K., Uekusa, H., Takagaki, M., Kimura, M., and Fujimura, M. 2009. Characterization of QoI resistance in Botrytis cinerea and identification of two types of mitochondrial cytochrome $b$ gene. Plant Pathol. 58:120-129.

Bartlett, D. W., Clough, J. M., Godwin, J. R., Hall, A. A., Hamer, M., and ParrDobrzanski, B. 2002. The strobilurin fungicides. Pest Manage. Sci. 58:649-662.

Birla, K., Rivera-Varas, V., Secor, G. A., Khan, M. F., and Bolton, M. D. 2012. Characterization of cytochrome b from European field isolates of Cercospora beticola with quinone outside inhibitor resistance. Eur. J. Plant Pathol. 134: 475-488.
Bobev, S. G., Groenewald, J. Z., and Crous, P. W. 2009. First report of Cercospora beticola as a pathogen of German statice (Goniolimon tataricum) in Bulgaria. Plant Dis. 93:553.

Bolton, M., Rivera, V., and Secor, G. 2012a. Identification of the G143A mutation associated with QoI resistance in Cercospora beticola field isolates from Michigan, United States. Pest Manage. Sci. 69:35-39.

Bolton, M., Rivera-Varas, V., Secor, G., Cattanach, A., and Metzger, M. 2013 Identification of the G143A mutation in cytochrome b associated with QoI resistance in Cercospora beticola isolates from the Red River Valley. Online publication. Plant Health Prog. doi:10.1094/PHP-2013-0812-02-RS.

Bolton, M. D., Secor, G. A., Rivera, V., Weiland, J. J., Rudolph, K., Birla, K., Rengifo, J., and Campbell, L. G. 2012b. Evaluation of the potential for sexual reproduction in field populations of Cercospora beticola from USA. Fungal Biol. 116:511-521.

Boukef, S., McDonald, B. A., Yahyaoui, A., Rezgui, S., and Brunner, P. C. 2012. Frequency of mutations associated with fungicide resistance and population structure of Mycosphaerella graminicola in Tunisia. Eur. J. Plant Pathol. 132: 111-122.

Bradley, C. A., and Pedersen, D. K. 2011. Baseline sensitivity of Cercospora zeae-maydis to quinone outside inhibitor fungicides. Plant Dis. 95:189-194.

Bruvo, R., Michiels, N. K., D’Souza, T. G., and Schulenburg, H. 2004. A simple method for the calculation of microsatellite genotype distances irrespective of ploidy level. Mol. Ecol. 13:2101-2106.

Castroagudín, V. L., Ceresini, P. C., de Oliveira, S. C., Reges, J. T. A., Maciel, J. L. N., Bonato, A. L. V., Dorigan, A. F., and McDonald, B. A. 2015. Resistance to QoI fungicides is widespread in Brazilian populations of the wheat blast pathogen Magnaporthe oryzae. Phytopathology 105:284-294.

Chen, W. J., Delmotte, F., Cervera, S. R., Douence, L., Greif, C., and Corio-Costet, M. F. 2007. At least two origins of fungicide resistance in grapevine downy mildew populations. Appl. Environ. Microbiol. 73:5162-5172.

Corio-Costet, M. F., Dufour, M. C., Cigna, J., Abadie, P., and Chen, W. J. 2011 Diversity and fitness of Plasmopara viticola isolates resistant to QoI fungicides. Eur. J. Plant Pathol. 129:315-329.

De Miccolis Angelini, R. M., Rotolo, C., Masiello, M., Pollastro, S., Ishii, H., and Faretra, F. 2012. Genetic analysis and molecular characterisation of laboratory and field mutants of Botryotinia fuckeliana (Botrytis cinerea) resistant to QoI fungicides. Pest Manage. Sci. 68:1231-1240.

Dorken, M. E., and Eckert, C. G. 2001. Severely reduced sexual reproduction in northern populations of a clonal plant, Decodon verticillatus (Lythraceae). J. Ecol. 89:339-350.

Estep, L. K., Torriani, S. F. F., Zala, M., Anderson, N. P., Flowers, M. D. McDonald, B. A., Mundt, C. C., and Brunner, P. C. 2015. Emergence and early evolution of fungicide resistance in North American populations of Zymoseptoria tritici. Plant Pathol. 64:961-971.

Excoffier, L., Laval, G., and Schneider, S. 2005. Arlequin ver. 3.0: An integrated software package for population genetics data analysis. Evol. Bioinf. 1:47-50.

Fernández-Ortuño, D., Torés, J. A., de Vicente, A., and Pérez-García, A. 2010. The QoI fungicides, the rise and fall of a successful class of agricultural fungicides. Pages 203-220 in: Fungicides. O. Carisse, ed. InTech, Rijeka, Croatia.

Fernández-Ortuño, D., Torés, J. A., de Vicente, A., and Pérez-García, A. 2008 Mechanisms of resistance to QoI fungicides in phytopathogenic fungi. Int. Microbiol. 11:1-9.

Fisher, N., and Meunier, B. 2008. Molecular basis of resistance to cytochrome bc inhibitors. FEMS Yeast Res. 8:183-192.

Franc, G. D. 2010. Ecology and epidemiology of Cercospora beticola. Pages 7-19 in: Cercospora Leaf Spot of Sugar Beet and Related Species. R. T. Lartey, J. J. Weiland, L. Panella, P. W. Crous, and C. E. Windels, eds. American Phytopathological Society, St. Paul, MN.

Fungicide Resistance Action Committee. 2013. List of plant pathogenic organisms resistant to disease control agents. Online publication. http://www.frac info/docs/default-source/publications/list-of-resistant-plant-pathogens/list-ofresistant-plant-pathogenic-organisms-february-2013.pdf?sfvrsn=4

Gisi, U., Sierotzki, H., Cook, A., and McCaffery, A. 2002. Mechanisms influencing the evolution of resistance to Qo inhibitor fungicides. Pest Manage. Sci. 58 859-867.

Groenewald, M., Groenewald, J. Z., Braun, U., and Crous, P. W. 2005. Distinct species exist within the Cercospora apii morphotype. Phytopathology 95: 951-959.

Groenewald, M., Groenewald, J. Z., Harrington, T. C., Abeln, E. C., and Crous, P. W. 2006. Mating type gene analysis in apparently asexual Cercospora species is suggestive of cryptic sex. Fungal Genet. Biol. 43:813-825.

Groenewald, M., Groenewald, J. Z., Linde, C. C., and Crous, P. W. 2007. Development of polymorphic microsatellite and single nucleotide polymorphism markers for Cercospora beticola (Mycosphaerellaceae). Mol. Ecol. Notes 7: 890-892.

Groenewald, M., Linde, C. C., Groenewald, J. Z., and Crous, P. W. 2008. Indirect evidence for sexual reproduction in Cercospora beticola populations from sugar beet. Plant Pathol. 57:25-32.

Hotegni Houessou, J. H., Beed, F., Sikirou, R., and Ezin, V. 2011. First report of Cercospora beticola on lettuce (Lactuca sativa) in Benin. New Dis. Rep. 23:16.

Ishii, H., Fountaine, J., Chung, W. H., Kansako, M., Nishimura, K., Takahashi, K., and Oshima, M. 2009. Characterisation of QoI-resistant field isolates of Botrytis cinerea from citrus and strawberry. Pest Manage. Sci. 65:916-922. 
Kamvar, Z. N., Tabima, J. F., and Grünwald, N. J. 2014. Poppr: An R package for genetic analysis of populations with clonal, partially clonal, and/or sexual reproduction. PeerJ 2:e281.

Kearse, M., Moir, R., Wilson, A., Stones-Havas, S., Cheung, M., Sturrock, S., Buxton, S., Cooper, A., Markowitz, S., Duran, C., Thierer, T., Ashton, B., Mentjies, P., and Drummond, A. 2012. Geneious Basic: An integrated and extendable desktop software platform for the organization and analysis of sequence data. Bioinformatics 28:1647-1649.

Khan, J., Rio, L. D., Nelson, R., Rivera-Varas, V., Secor, G. A., and Khan, M. F. R. 2008. Survival, dispersal, and primary infection site for Cercospora beticola in sugar beet. Plant Dis. 92:741-745.

Kim, Y. S., Dixon, E. W., Vincelli, P., and Farman, M. L. 2003. Field resistance to strobilurin (QoI) fungicides in Pyricularia grisea caused by mutations in the mitochondrial cytochrome $b$ gene. Phytopathology 93:891-900.

Kirk, W. W., Hanson, L. E., Franc, G. D., Stump, W. L., Gachango, E., Clark, G., and Stewart, J. 2012. First report of strobilurin resistance in Cercospora beticola in sugar beet (Beta vulgaris) in Michigan and Nebraska, USA. New Dis. Rep. 26:3.

Koike, S. T., du Toit, L. J., and Abawi, G. S. 2010. Cercospora leaf spot of vegetable crops in the Chenopodiaceae. Pages 91-96 in: Cercospora Leaf Spot of Sugar Beet and Related Species. R. T. Lartey, J. J. Weiland, L. Panella, P. W. Crous, and C. E. Windels, eds. American Phytopathological Society, St. Paul, MN.

Lartey, R. T., Caesar-Ton That, T. C., Caesar, A. J., Shelver, W. L., Sol, N. I., and Bergman, J. W. 2005. Safflower: A new host of Cercospora beticola. Plant Dis. 89:797-801.

Leroux, P., Gredt, M., Leroch, M., and Walker, A. S. 2010. Exploring mechanisms of resistance to respiratory inhibitors in field strains of Botrytis cinerea, the causal agent of gray mold. Appl. Environ. Microbiol. 76:6615-6630.

Lesniak, K. E., Proffer, T. J., Beckerman, J. L., and Sundin, G. W. 2011. Occurrence of $\mathrm{QO}_{\mathrm{O}} \mathrm{I}$ resistance and detection of the G143A mutation in Michigan populations of Venturia inaequalis. Plant Dis. 95:927-934.

Ma, Z., Felts, D., and Michailides, T. J. 2003. Resistance to azoxystrobin in Alternaria isolates from pistachio in California. Pestic. Biochem. Physiol. 77: 66-74.

Malandrakis, A. A., Markoglou, A. N., Nikou, D. C., Vontas, J. G., and Ziogas, B. N. 2006. Biological and molecular characterization of laboratory mutants of Cercospora beticola resistant to Qo inhibitors. Eur. J. Plant Pathol. 116: 155-166.

Malandrakis, A. A., Markoglou, A. N., Nikou, D. C., Vontas, J. G., and Ziogas, B. N. 2011. Molecular diagnostic for detecting the cytochrome b G143S-QoI resistance mutation in Cercospora beticola. Pestic. Biochem. Physiol. 100: 87-92.

Markoglou, A. N., Malandrakis, A. A., Vitoratos, A. G., and Ziogas, B. N. 2006. Characterization of laboratory mutants of Botrytis cinerea resistant to QoI fungicides. Eur. J. Plant Pathol. 115:149-162.

Maynard Smith, J., Feil, E. J., and Smith, N. H. 2000. Population structure and evolutionary dynamics of pathogenic bacteria. BioEssays 22:1115-1122.

McDonald, B. A., and Linde, C. 2002. Pathogen population genetics, evolutionary potential, and durable resistance. Annu. Rev. Phytopathol. 40:349-379.

McKay, M. B., and Pool, V. W. 1918. Field studies of Cercospora beticola. Phytopathology 8:119-136.

Meirmans, P. G., and van Tienderen, P. H. 2004. GENOTYPE and GENODIVE: Two programs for the analysis of genetic diversity of asexual organisms. Mol. Ecol. Notes 4:792-794.

Milgroom, M. G. 1996. Recombination and the multilocus structure of fungal populations. Annu. Rev. Phytopathol. 34:457-477.

Moretti, M., Karaoglanidis, G., Saracchi, M., Fontana, A., and Farina, G. 2006. Analysis of genotypic diversity in Cercospora beticola Sacc. field isolates. Ann. Microbiol. 56:215-221.

Moretti, M., Saracchi, M., and Farina, G. 2004. Morphological, physiological and genetic diversity within a small population of Cercospora beticola Sacc. Ann. Microbiol. 54:129-150.

Nei, M. 1987. Molecular Evolutionary Genetics. Columbia University Press, New York.

Obuya, J., Hanson, L., and Franc, G. 2011. Mating type idiomorphs distribution and their correlation to benzimidazole-resistance in Cercospora beticola from the Central High Plains Region, USA. J. Sugar Beet Res. 48:101-102.

Olaya, G., and Abawi, G. S. 1994. Characteristics of Rhizoctonia solani and binucleate Rhizoctonia species causing foliar blight and root rot on table beets in New York State. Plant Dis. 78:800-804.

Olaya, G., Cleere, S., Stanger, C., Burbidge, J., Hall, A., and Windass, J. 2003. A novel potential target site QoI fungicide resistance mechanism in Pythium aphanidermatum. (Abstr.) Phytopathology 93:S67.

Pang, S. Y. M., Tristram, S., and Brown, S. 2011. Salicylhydroxamic acid inhibits the growth of Candida albicans. Int. J. Biol. Life Sci. 7:40-46.

Pasche, J. S., Piche, L. M., and Gudmestad, N. C. 2005. Effect of the F129L mutation in Alternaria solani on fungicides affecting mitochondrial respiration. Plant Dis. 89:269-278.
Peakall, R. O. D., and Smouse, P. E. 2006. GENALEX 6: Genetic analysis in Excel. Population genetic software for teaching and research. Mol. Ecol. Notes 6:288-295

Pompanon, F., Bonin, A., Bellemain, E., and Taberlet, P. 2005. Genotyping errors: Causes, consequences and solutions. Nat. Rev. Genet. 6:847-859.

Pool, V. W., and McKay, M. B. 1916. Climatic conditions as related to Cercospora beticola. J. Agric. Res. 6:21-60.

Price, P., Purvis, M. A., Cai, G., Padgett, G. B., Robertson, C. L., Schneider, R. W., and Albu, S. 2015. Fungicide resistance in Cercospora kikuchii, a soybean pathogen. Plant Dis. 99:1596-1603.

Rooney-Latham, S., Scheck, H. J., and Walber, T. M. 2011. First report of Cercospora beticola causing a leaf spot disease on Acanthus mollis in California. Plant Dis. 95:224.

Rosenzweig, N., Hanson, L. E., Clark, G., Franc, G. D., Stump, W. L., Jiang, Q. W., Stewart, J., and Kirk, W. W. 2015. Use of PCR-RFLP analysis to monitor fungicide resistance in Cercospora beticola populations from sugarbeet (Beta vulgaris) in Michigan, United States. Plant Dis. 99:355-362.

Secor, G. A., and Rivera, V. V. 2011. Fungicide resistance assays for fungal plant pathogens. Pages 385-392 in: Plant Fungal Pathogens: Methods and Protocols. M. D. Bolton and B. P. H. J. Thomma, eds. Humana Press, New York

Semar, M., Strobel, D., Koch, A., Klappach, K., and Stammler, G. 2007. Field efficacy of pyraclostrobin against populations of Pyrenophora teres containing the F129L mutation in the cytochrome $b$ gene. J. Plant Dis. Prot. 114:117-119.

Sierotzki, H., Frey, R., Wullschleger, J., Palermo, S., Karlin, S., Godwin, J., and Gisi, U. 2007. Cytochrome $b$ gene sequence and structure of Pyrenophora teres and $P$. tritici-repentis and implications for QoI resistance. Pest Manage. Sci. 63:225-233.

Sierotzki, H., Kraus, N., Pepin, S., Fernandes, N., and Gisi, U. 2008. Dynamics of QoI resistance in Plasmopara viticola. Pages 151-157 in: Modern Fungicides and Antifungal Compounds: 5th Int. Reinhardsbrunn Symp. Friedrichroda. H. W. Dehne, H. B. Deising, K. H. Kuck, P. E. Russell, and H. Lyr, eds. Deutsche Phytomedizinische Gesellschaft, Braunschweig, Germany.

Sierotzki, H., Wullschleger, J., and Gisi, U. 2000. Point mutation in cytochrome b gene conferring resistance to strobilurin fungicides in Erysiphe graminis $\mathrm{f}$. $\mathrm{sp}$ tritici field isolates. Pestic. Biochem. Physiol. 68:107-112.

Turgay, E. B., Bakir, M., Ozeren, P., Katircioglu, Y. Z., and Maden, S. 2010. Detection of pathotypes and genetic diversity of Cercospora beticola. Plant Pathol. J. 26:306-312.

United Stated Department of Agriculture National Agricultural Statistics Service. 2012. 2012 Census of Agriculture. Online publication. USDA-NASS, Washington, DC. http://www.agcensus.usda.gov/Publications/2012/

Vereijssen, J. 2004. Cercospora leaf spot in sugar beet: Epidemiology, life cycle components and disease management. Doctoral dissertation, Wageningen University and Research Centre, Wageningen, The Netherlands.

Vereijssen, J., Schneider, J. H. M., and Jeger, M. J. 2007. Epidemiology of Cercospora leaf spot on sugar beet: Modeling disease dynamics within and between individual plants. Phytopathology 97:1550-1557.

Vereijssen, J., Schneider, J. H. M., Stein, A., and Jeger, M. J. 2006. Spatial pattern of Cercospora leaf spot of sugar beet in fields in long-and recently-established areas. Eur. J. Plant Pathol. 116:187-198.

Vestal, E. F. 1933. Pathogenicity, host response and control of Cercospora leafspot of sugar beets. Res. Bull. No 168. Agricultural Experiment Station, Iowa State College of Agriculture and Mechanic Arts, Ames.

Watanabe, H., Kuwabara, K., Tsueda, H., Horinouchi, H., and Ishii, H. 2009. Occurrence of azoxystrobin-resistant Passalora fulva pathogen of tomato leaf mold. (Abstract in Japanese). Jpn. J. Phytopathol. 75:247.

Weiland, J., Eide, J., Rivera-Varas, V., and Secor, G. 2001. Genetic diversity of Cercospora beticola in the U.S. and association of molecular markers with tolerance to the fungicide triphenyltin hydroxide (TPTH). (Abstr.) Phytopathology 91:S94

Weiland, J., and Koch, G. 2004. Sugarbeet leaf spot disease (Cercospora beticola Sacc.). Mol. Plant Pathol. 5:157-166.

Wood, P. M., and Hollomon, D. W. 2003. A critical evaluation of the role of alternative oxidase in the performance of strobilurin and related fungicides acting at the Qo site of complex III. Pest Manage. Sci. 59:499-511.

Yamada, K., and Sonoda, R. 2012. Characterization of moderate resistance to QoI fungicides in Pestalotiopsis longiseta and polymorphism in exon-intron structure of cytochrome b gene. J. Gen. Plant Pathol. 78:398-403.

Young, J. R., Tomaso-Peterson, M., Tredway, L. P., and de la Cerda, K. 2010 Occurrence and molecular identification of azoxystrobin-resistant Colletotrichum cereale isolates from golf course putting greens in the southern United States. Plant Dis. 94:751-757.

Zhan, J., and McDonald, B. A. 2013. Experimental measures of pathogen competition and relative fitness. Annu. Rev. Phytopathol. 51:131-153.

Zhang, G., Pedersen, D. K., Phillips, D. V., and Bradley, C. A. 2012. Sensitivity of Cercospora sojina isolates to quinone outside inhibitor fungicides. Crop Prot. 40:63-68

Ziogas, B. N., Baldwin, B. C., and Young, J. E. 1997. Alternative respiration: A biochemical mechanism of resistance to azoxystrobin in Septoria tritici. Pestic. Sci. 50:28-34. 